\title{
Mössbauer and Raman characterization of ash produced by burning ancient buried Japanese cedar and investigation for its unusual color tone
}

\author{
Shigeru Yamauchi ${ }^{1} \cdot$ Yasuji Kurimoto $^{1} \cdot$ Tsutomu Takayama $^{2} \cdot$ Yoichi Sakai $^{2}$
}

Received: 19 June 2020 / Published online: 28 August 2020

(c) The Author(s) 2020

\begin{abstract}
Mössbauer and Raman spectroscopic characterization of colored ash samples made by combustion of ancient buried Japanese cedar (Cryptomeria japonica) was carried out, and the factors governing the color tones were investigated mainly in terms of the chemical species of $\mathrm{Fe}$. The ash samples displayed various unusual colors, depending clearly on the individual ancient tree and the part of it. Some of Mössbauer spectra of the ash samples showed magnetic hyperfine splittings due to internal magnetic fields. The Mössbauer and Raman spectra suggested that the primary Fe-containing species in all the ash samples was calcium ferrite, $\mathrm{Ca}_{2} \mathrm{Fe}_{2} \mathrm{O}_{5}$.
\end{abstract}

Keywords Mössbauer spectroscopy $\cdot$ Raman spectroscopy $\cdot$ Calcium ferrite $\cdot$ Ancient buried wood $\cdot$ Superparamagnetic effect

\begin{tabular}{|c|c|}
\hline \multicolumn{2}{|c|}{ Abbreviations } \\
\hline XRD & $\mathrm{X}$-ray diffraction \\
\hline UWX & $(\mathrm{X}=1-1,1-2$, and 2$)$ is an umoregi-wood sam \\
\hline UAX & $\begin{array}{l}(\mathrm{X}=1-1,1-2, \text { and } 2) \text { is an ash sample made fr } \\
\text { UWX }\end{array}$ \\
\hline MA & $\begin{array}{l}\text { Is an ash sample made from modern Japanese } \\
\text { cedar wood }\end{array}$ \\
\hline $\mathrm{MBq}$ & Megabecquerel \\
\hline$I S$ & Isomer shift \\
\hline$Q S$ & Quadrupole splitting \\
\hline$L W$ & Line width \\
\hline$H$ & Internal magnetic field \\
\hline $\mathrm{T}$ & Tesla \\
\hline$O_{h}$ & Octahedral \\
\hline$T_{d}$ & Tetrahedral \\
\hline
\end{tabular}

Shigeru Yamauchi

sigeru@iwt.akita-pu.ac.jp

1 Institute of Wood Technology, Akita Prefectural University, Noshiro, Akita 016-0876, Japan

2 Department of Chemistry, Daido University, Nagoya, Aichi 457-0819, Japan

\section{Introduction}

As described in our previous studies [1-3], "umoregi" is the most common Japanese term that refer to ancient trees buried or submerged as a result of natural phenomena (e.g., landslides, debris, avalanches, and ground subsidence) over several centuries ago. This term is generally applied to the ancient trees that have not been substantially denatured in terms of their physical properties and main chemical constituents. In English, the terms, bog wood, fossil wood (or sub-fossil wood), lignite, etc. have been utilized as translations of umoregi; however, the meaning of these English terms is not exactly equivalent to that of the Japanese term.

Owing to its attractive color tones, umoregi wood is regarded as a special woody material. Furthermore, experts or advanced learners of the Japanese tea or traditional incense ceremonies rate the ash made from umoregi wood, which displays various unusual colors, as top-quality ash in an incense burner or a brazier. However, there have been no reports examining the ash made from umoregi wood other than our previous work [1]. We investigated the coloring mechanism of ash obtained from the combustion of four species of umoregi trees excavated from the foothills of Mt. Chokai in 2015 [1]. The Mössbauer spectra of some ash samples made from umoregi wood showed obvious magnetic hyperfine splittings; however, satisfactory curve-fitting analysis could not be carried out, owing to the broad and 
complicated absorption line-shapes. We revealed in our previous report [1] that the umoregi-wood ash samples included calcium ferrites, $\mathrm{CaFe}_{2} \mathrm{O}_{4}$ and/or $\mathrm{Ca}_{2} \mathrm{Fe}_{2} \mathrm{O}_{5}$, from our qualitative analysis of the Mössbauer spectral line-shapes, speculating that the calcium ferrites governed the color of the umoregi-wood ash samples. However, it is not sufficiently confirmative to make clear the formation of calcium ferrites and to explain more comprehensively the factors affecting the color tone of umoregi-wood ash.

We obtained ash samples with different colors made from Japanese cedar (Cryptomeria japonica) umoregi wood excavated within the same zone of the mountainside of Mt. Chokai, which stands on the boundary between Akita and Yamagata Prefectures, Japan, as shown in Fig. 1, and attempted to clarify the factors governing the color tones of the samples, based on the Mössbauer and Raman characterization.

\section{Experimental}

\section{Japanese cedar umoregi trees}

The Japanese cedar umoregi trees used in this study were dug up in 2018 from Nikaho City in Akita Prefecture, Japan, at a location to the north-west of Mt. Chokai. The excavation point was located at $39^{\circ} 13^{\prime} 44^{\prime \prime}$ north latitude and $139^{\circ}$ $58^{\prime} 4^{\prime \prime}$ east longitude. Heavy landslides are known to have occurred over the north-west foothills of Mt. Chokai about 2500 years ago, and the umoregi trees were probably buried by these landslides [4].

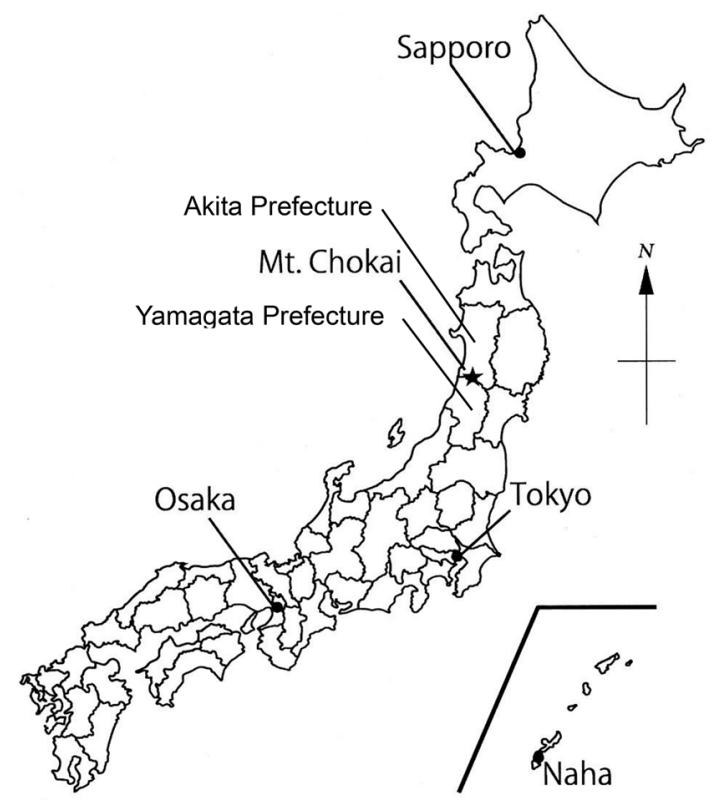

Fig. 1 The location of Mt. Chokai in Japan

\section{Umoregi-wood ash samples and chemicals}

Ash samples were prepared by combustion of the Japanese cedar umoregi-wood and modern-wood in an ordinary open-type electric furnace maintained at $600{ }^{\circ} \mathrm{C}$ for $7 \mathrm{~h}$. The samples obtained were submitted to analytical measurements without further grinding. The mass percentage of the ash to the wood powder dried at $105^{\circ} \mathrm{C}$ was defined here as the value of the ash content. Special-grade calcium carbonate $\left(\mathrm{CaCO}_{3}\right)$ powder used as a reference substance was purchased from Fujifirm Wako Pure Chemical Corporation.

\section{X-ray fluorescence spectrometry}

The content of elements from $\mathrm{Na}$ to Ba present in the Japanese cedar umoregi-wood and modern-wood ash were determined by X-ray fluorescence (XRF) spectrometry using a compact spectrometer (JSX-1000S, Jeol, Ltd., Japan). The ash samples (0.25-0.28 g) were placed in a cylindrical cell with a diameter of $20 \mathrm{~mm}$. The sample chamber of the compact spectrometer was evacuated using an oil-sealed rotary vacuum pump during measurements. $\mathrm{X}$-ray irradiation was performed at room temperature for a measurement time of $30 \mathrm{~s}$. The X-ray spot on the ash samples was an oval $(9 \mathrm{~mm} \times 10 \mathrm{~mm})$. The $\mathrm{X}$-ray tube voltage was $30 \mathrm{kV}$.

\section{Raman spectroscopy}

Raman spectra were obtained using a Raman spectrometer (inVia Raman Microscope, Renishaw PLC, UK) with $532 \mathrm{~nm}$ laser excitation $(0.75-1.5 \mathrm{~mW})$. Back-scattered Raman signals were collected through a microscope (50 $\times$ objective lens) with a spectral resolution of $3 \mathrm{~cm}^{-1}$, and the exposure time was $50 \mathrm{~s}$. The ash samples were thinly and evenly spread on a glass plate. The diameter of the laser spot on the sample surface was $\sim 2 \mu \mathrm{m}$. Since such a measurement-scope is much smaller relative to the homogeneity-scale of sample, Raman measurements were repeated at more than 30 different points for each ash sample in the present work. The calibration of Raman shifts was carried out using the 520 and $1332 \mathrm{~cm}^{-1}$ for a silicon wafer and diamond, respectively.

\section{Powder X-ray diffractometry}

X-ray diffraction (XRD) analysis was performed using a Shimadzu XRD-7000 X-ray diffractometer (Shimadzu 
Corp., Japan) equipped with a $\mathrm{Cu}-\mathrm{K} \alpha$ radiation source (wavelength: $1.5406 \AA$ ). Diffraction patterns were acquired at $30 \mathrm{kV}$ and $30 \mathrm{~mA}$ in a line focus mode. Scan rates were set at $4 \% \mathrm{~min}$.

\section{Mössbauer spectroscopy}

${ }^{57} \mathrm{Fe}$ Mössbauer spectra were recorded using a Mössbauer spectrometer (Model-222, Topologic System Inc., Japan) with a ${ }^{57} \mathrm{Co}(\mathrm{Rh})$ source $(925 \mathrm{MBq})$ in an ordinary transmission mode. The $\gamma$-ray transmission diameter of the ash samples was approximately $8 \mathrm{~mm}$. Measurement temperatures were $298 \mathrm{~K}$ and $78 \mathrm{~K}$, and they were regulated using an Oxford cryostat DN-1726 with a temperature controller of ITC-601. Two kinds of curve-fitting were carried out in the numerical analysis of the Mössbauer spectra by using of a commercially available computing-program named MossWinn 4.0i. Firstly, the Mössbauer spectra measured in this study were curve-fitted using an ordinary method, assuming that they consist only of Lorentzian-shaped lines. If this method failed to obtain the reasonable values of Mössbauer parameters, the second method was applied to the curve-fitting procedure with a distribution of Mössbauer parameters. The isomer shift $(I S)$ values and Doppler velocity scale were calibrated with respect to $\alpha-\mathrm{Fe}$ at room temperature.

The Fe-thicknesses of umoregi-wood ash samples were in the 7.4-9.6 mg/ $\mathrm{cm}^{2}$ ranges, which allowed us to discuss a Mössbauer absorption intensity proportional to its ironspecies concentration approximately.

\section{Results and discussion}

\section{Color tone of Japanese cedar umoregi wood}

Figure 2 shows photos of two Japanese cedar umoregiwood specimens obtained from different individual trees.
As shown in the figure, from specimen 1 (umoregi wood 1: UW1) two parts were sampled as heartwood (UW1-1) and sapwood (UW1-2). It should be noted that UW1-1 and UW1-2 are distinguishable by their entirely different color tones, like modern wood. Specimen 2 (umoregi wood 2: UW2) is most likely composed of only heartwood. It looks that the color tone of UW1-1 is somewhat different from that of UW2.

\section{Color tone of umoregi-wood ash}

Figure 3 shows photographs of three ash samples made from the two specimens of Japanese cedar umoregi wood. The
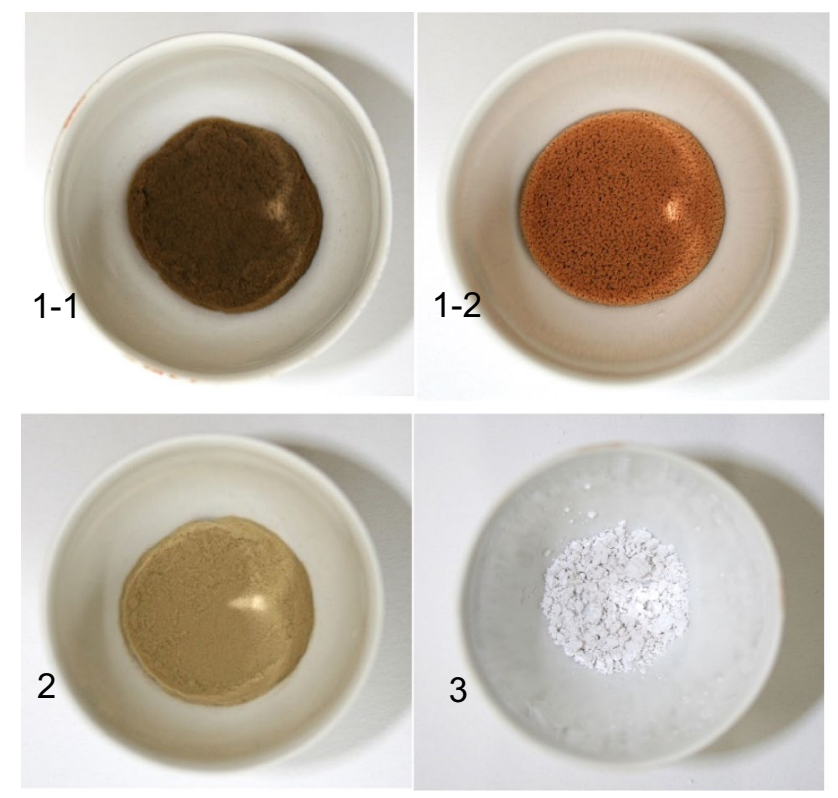

Fig. 3 Photographs of ash samples made from Japanese cedar umoregi wood and modern Japanese cedar wood for (1-1) UA1-1, (1-2) UA1-2, (2) UA2, and (3) MA UAX and MA were made from UWX $(X=1-1,1-2$, and 2$)$ and modern Japanese cedar wood, respectively
Fig. 2 Photographs of cross sections of three parts of two Japanese cedar umoregi wood specimens for (1-1) UW1-1: heartwood, (1-2) UW1-2: sapwood, and (2) UW2: heartwood
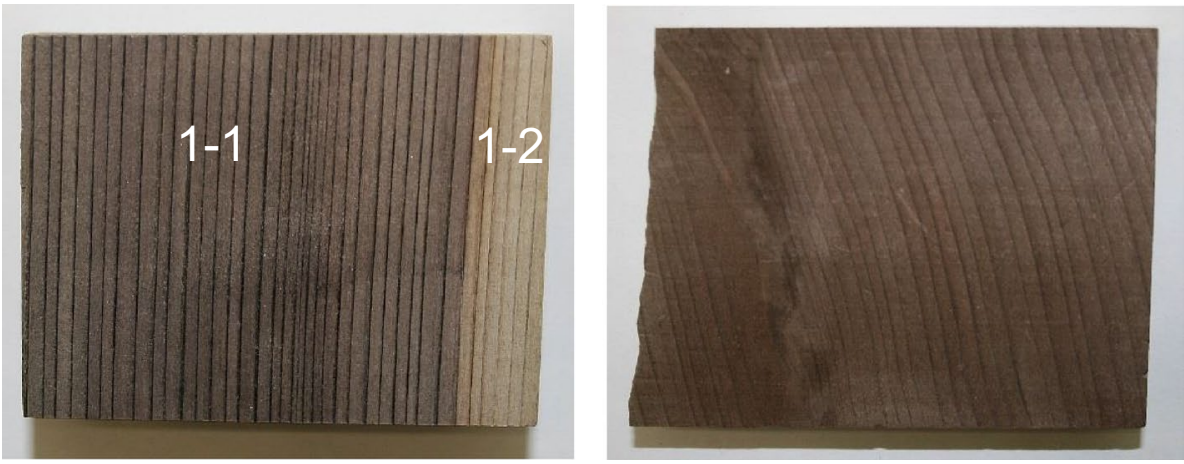
ash made from $\mathrm{UWX}(\mathrm{X}=1-1,1-2$, and 2$)$ is abbreviated as UAX. The photo of modern Japanese cedar wood ash (MA), of which the color turns completely white, is shown as a reference. The three UA samples show characteristic colors and they are quite different from one another. The colors of UA1-1 and UA1-2 are dark brown and orangecolored, respectively. In contrast, that of UA2 is grayishyellow. Interestingly, the color tone of ash made from sapwood (UA1-2) is clearly different from that of ash made from heartwood (UA1-1), despite the fact that both UA1-1 and UA1-2 were obtained from the same Japanese cedar umoregi tree.

\section{Elements in ash samples}

The molar percentages of elements from $\mathrm{Na}$ to $\mathrm{Ba}$ in UAX $(\mathrm{X}=1-1,1-2$, and 2$)$ and MA determined using XRF spectrometry are listed in Table 1 . The elements for which the molar percentage is less than $0.10 \%$ are omitted from the table. As is expected from the previous study [1], Fe was concentrated considerably in the three umoregi-wood ash samples compared with MA. The XRF elemental-analysis results could provide two important pieces of information about the Fe-containing species.

The first information is on the $\mathrm{Fe} / \mathrm{Ca}$ molar ratio. Hirabayashi have reported that the production ratio of $\mathrm{CaFe}_{2} \mathrm{O}_{4} /$ $\mathrm{Ca}_{2} \mathrm{Fe}_{2} \mathrm{O}_{5}$ would be dependent on the $\mathrm{Fe} / \mathrm{Ca}$ ratio in the synthesis from $\mathrm{Fe}_{2} \mathrm{O}_{3}$ and $\mathrm{CaO}$ [5]. As shown in Table 1, $\mathrm{Fe}$ and

Table 1 Molar percentages of elements as an ordinary-type oxide in ash samples

\begin{tabular}{|c|c|c|c|c|}
\hline Ash samples & UA1-1 & UA1-2 & UA2 & MA \\
\hline$C_{\mathrm{ash}}(\mathrm{wt} \%)$ & 0.57 & 0.76 & 0.91 & 0.24 \\
\hline $\mathrm{Na}_{2} \mathrm{O}$ & $5.04(19)$ & $3.23(16)$ & $23.47(30)$ & $1.23(11)$ \\
\hline $\mathrm{MgO}$ & $13.82(11)$ & $12.67(11)$ & $7.83(9)$ & $5.81(6)$ \\
\hline $\mathrm{Al}_{2} \mathrm{O}_{3}$ & $0.30(2)$ & $0.62(3)$ & $0.20(2)$ & $0.23(1)$ \\
\hline $\mathrm{SiO}_{2}$ & $3.87(3)$ & $2.15(2)$ & $2.75(3)$ & - \\
\hline $\mathrm{P}_{2} \mathrm{O}_{5}$ & $0.20(1)$ & $3.10(3)$ & $0.36(1)$ & $0.95(1)$ \\
\hline $\mathrm{SO}_{3}$ & $1.88(1)$ & $16.74(4)$ & $0.99(1)$ & $1.24(1)$ \\
\hline $\mathrm{K}_{2} \mathrm{O}$ & $1.00(1)$ & $0.80(1)$ & $1.14(1)$ & $13.34(4)$ \\
\hline $\mathrm{CaO}$ & $48.73(6)$ & $42.23(6)$ & $53.80(7)$ & $76.44(7)$ \\
\hline $\mathrm{TiO}_{2}$ & - & 0.17 (1) & - & - \\
\hline $\mathrm{MnO}$ & $0.66(1)$ & $0.55(1)$ & $0.19 *$ & $0.21 *$ \\
\hline $\mathrm{Fe}_{2} \mathrm{O}_{3}$ & $24.19(5)$ & $17.52(4)$ & 8.99 (3) & $0.10 *$ \\
\hline $\mathrm{SrO}$ & - & - & $0.11 *$ & $0.20 *$ \\
\hline $\mathrm{BaO}$ & $0.16(1)$ & $0.11(1)$ & 0.18 (1) & $0.16(1)$ \\
\hline
\end{tabular}

UAX was ash made from UWX (X=1-1, 1-2, and 2)

MA was ash made from modern Japanese cedar wood

$C_{\text {ash }}$ is an ash content of umoregi wood

- indicates "not detected" or "less than 0.10 "

*Standard deviation is less than 0.01
$\mathrm{Ca}$ are primary elements in all the ash samples; therefore, the chemical species containing Fe and/or Ca would substantially influence the color tone of the ash samples.

The second is the contents of $\mathrm{Na}$ and $\mathrm{Mg}$ that can form ferrites. $\mathrm{Na}$ and $\mathrm{Mg}$ are secondary elements in UA1-1 and UA1-2, and their molar percentages are so large that they cannot be ignored. As for UA2, Na is one of primary elements as well as $\mathrm{Ca}$ and $\mathrm{Fe}$. Hence, all the umoregi-wood ash samples may comprise multiple species of ferrite. Furthermore, it is expected that $\mathrm{Na}, \mathrm{Mg}$, and $\mathrm{Ca}$ were partly formed as their oxides in the ash samples, especially UA2, because the total molar percentages of $\mathrm{Na}, \mathrm{Ma}$, and $\mathrm{Ca}$ are excessively large compared with those of $\mathrm{Fe}$ in the ash samples. This will be discussed in detail later.

In addition, UA1-2 contains a considerable amount of $\mathrm{S}$ and $\mathrm{P}$, compared with other samples. The abundance of $\mathrm{S}$ and $\mathrm{P}$ might exert some influence on the color of the ash samples. Transition metals, $\mathrm{Ti}$ and $\mathrm{Mn}$, which have the potential to affect the color tone of umoregi-wood ash were also present; however, their molar percentages are much lower than those of Fe. Accordingly, the effects of these elements on the color tone will be negligible.

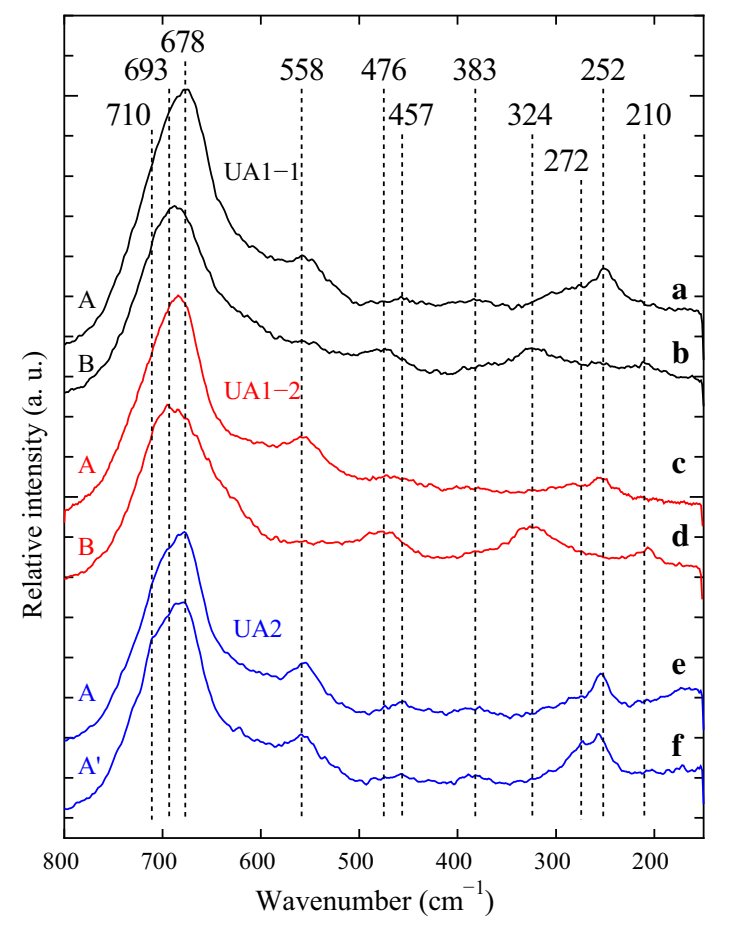

Fig. 4 Raman spectra in the range $800-150 \mathrm{~cm}^{-1}$ of ash samples for a and b UA1-1 (black solid line), $\mathbf{c}$ and d UA1-2 (red solid line), e and (f) UA2 (blue solid line) UAX was made from UWX (X=1-1, 1-2, and 2). Spectra $\mathbf{a}, \mathbf{c}$ and $\mathbf{e}$ belong to pattern A. Spectra $\mathbf{b}$ and $\mathbf{d}$ belong to pattern $\mathrm{B}$. Spectrum $\mathbf{f}$ belongs to pattern $\mathrm{A}^{\prime}$ 


\section{Raman spectra of ash samples}

Figure 4 illustrates two kinds of typical Raman spectrum of each umoregi-wood ash sample in the range from $800 \mathrm{~cm}^{-1}$ to $150 \mathrm{~cm}^{-1}$. Almost all the Raman spectra of UA1-1 and UA1-2 were roughly classified into two patterns, A and B, showing spectral line-shapes different from each other. The Raman spectra shown in Figs. 4a, c corresponds to the spectral pattern A, and those shown in Figs. 4b, d belong to the pattern B. In contrast, almost the Raman spectra of UA2 showed pattern A; however, a Raman band was observed at $272 \mathrm{~cm}^{-1}$ in a few spectra. This spectral pattern is referred to $\mathrm{A}^{\prime}$.

In Table 2 are summarized the Raman band frequencies of the ash samples in this work, where those of calcium [6-8], magnesium [9, 10], and sodium [11] ferrites reported previously are also presented for a comparison. It is evidently exhibited in the table that all the ash samples contain $\mathrm{CaFe}_{2} \mathrm{O}_{4}$ and/or $\mathrm{Ca}_{2} \mathrm{Fe}_{2} \mathrm{O}_{5}$; however, it is difficult to distinguish the two calcium ferrites based only on the Raman bands detected in this region because of no significant differences in Raman bands between the two ferrites [6-8].

Observations of the Raman bands at 324 and $476 \mathrm{~cm}^{-1}$ in the spectral pattern B might suggest that UA1-1 and UA1-2 comprise small amounts of magnesium ferrite, $\mathrm{MgFe}_{2} \mathrm{O}_{4}$. The crystal structure of sodium ferrite, $\mathrm{NaFeO}_{2}$, is a rock salt $(\alpha)$ or zinc blend ( $\beta$ ) type. A number of studies on the compounds with the same structure as $\mathrm{NaFeO}_{2}$ have been reported; nevertheless, there have been few Raman spectroscopic studies on $\mathrm{NaFeO}_{2}$ in itself. The Raman band frequencies of $\alpha$ - and $\beta-\mathrm{NaFeO}_{2}$ listed in Table 2 were estimated from the spectra illustrated in the literature [11]. As can be seen in Fig. 4, the Raman band at $457 \mathrm{~cm}^{-1}$ observed in the spectra of $\mathrm{A}$ and $\mathrm{A}^{\prime}$ patterns may indicate the presence of $\beta-\mathrm{NaFeO}_{2}$. This assignment of the band at $457 \mathrm{~cm}^{-1}$ is probably supported by the fact that UA2 is the most Narich ash sample, and the relative intensities of the band in the spectra of UA2 are obviously stronger than those of UA1-1 and UA1-2. Finally, the results obtained from Raman measurements in the $800-150 \mathrm{~cm}^{-1}$ region suggest

Table 2 Raman band frequencies of ash samples and calcium, magnesium, and sodium ferrites reported in the previous works

\begin{tabular}{|c|c|c|c|c|c|c|c|c|}
\hline \multicolumn{2}{|c|}{ Umoregi-wood ash samples } & \multirow[t]{2}{*}{$\mathrm{CaFe}_{2} \mathrm{O}_{4}$} & \multirow[t]{2}{*}{$\mathrm{Ca}_{2} \mathrm{Fe}_{2} \mathrm{O}_{5}$} & \multirow[t]{2}{*}{$\mathrm{Ca}_{2} \mathrm{Fe}_{2} \mathrm{O}_{5}$} & \multirow[t]{2}{*}{$\mathrm{MgFe}_{2} \mathrm{O}_{4}$} & \multirow[t]{2}{*}{$\mathrm{MgFe}_{2} \mathrm{O}_{4}$} & \multirow[t]{2}{*}{$\alpha-\mathrm{NaFeO}_{2}$} & \multirow[t]{2}{*}{$\beta-\mathrm{NaFeO}_{2}$} \\
\hline Patterns $A$ and $\mathrm{A}^{\prime}$ & Pattern B & & & & & & & \\
\hline \multicolumn{9}{|l|}{ Raman shift $\left(\mathrm{cm}^{-1}\right)$} \\
\hline & 210 & 213 & & 212 & & & & \\
\hline & & & & & 217 & 217 & 220 & \\
\hline \multirow[t]{2}{*}{252} & & 252 & 251 & 254 & & & & \\
\hline & & 258 & 261 & & & & & 260 \\
\hline \multicolumn{9}{|l|}{$272 *$} \\
\hline & & 288 & 292 & 290 & & & & 305 \\
\hline & & 315 & 313 & 312 & & & & \\
\hline & 324 & & & & & 327 & & \\
\hline & & & & & 333 & & & \\
\hline & & & & & & & 350 & \\
\hline & & & & & & 367 & & \\
\hline \multirow[t]{4}{*}{383} & & 379 & 380 & 379 & & & & \\
\hline & & 395 & 393 & 395 & & & & \\
\hline & & & & & & & & 415 \\
\hline & & 428 & 428 & 427 & & & & \\
\hline \multirow[t]{2}{*}{457} & & & & & & & & 455 \\
\hline & 476 & & & & 486 & 487 & & \\
\hline \multirow[t]{3}{*}{558} & & 558 & 558 & 555 & 554 & 550 & 566 & \\
\hline & & 600 & 595 & & & 590 & & 600 \\
\hline & & & & & 646 & 630 & & \\
\hline \multirow[t]{2}{*}{678} & & & & $667^{\text {sh }}$ & & & & \\
\hline & 693 & & & & & & & \\
\hline $710^{*}, \mathrm{sh}$ & & 703 & 705 & 706 & 715 & 703 & & \\
\hline This study & Ref. [6] & Ref. [7] & Ref. [8] & Ref. [9] & Ref. [10] & Ref. [11] & Ref. [11] & \\
\hline
\end{tabular}

*The band was observed only in the pattern $\mathrm{A}^{\prime}$ spectra $s h$ shoulder 


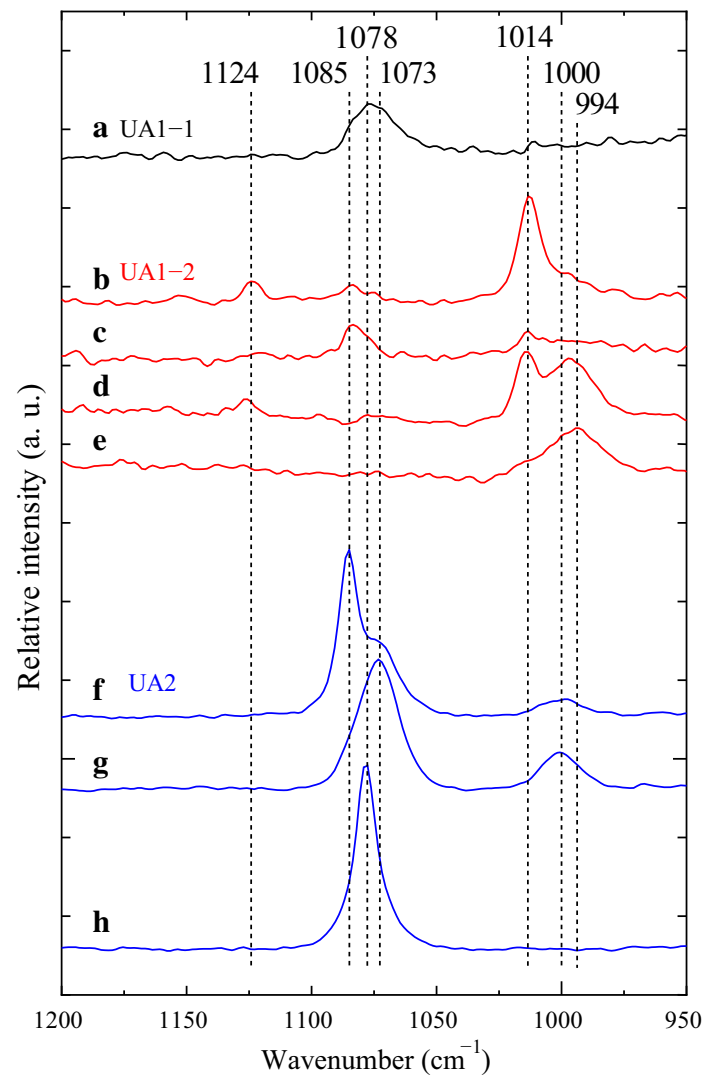

Fig. 5 Raman spectra in the range $1200-950 \mathrm{~cm}^{-1}$ of ash samples for a UA1-1 (black solid line), b-e UA1-2 (red solid line), f, $\mathbf{g}$, and (h) UA2 (blue solid line) UAX was made from UWX (X=1-1, 1-2, and 2)

that the three ash samples contain calcium ferrites, $\mathrm{CaFe}_{2} \mathrm{O}_{4}$ and/or $\mathrm{Ca}_{2} \mathrm{Fe}_{2} \mathrm{O}_{5}$, as major components, and other ferrites, $\mathrm{MgFe}_{2} \mathrm{O}_{4}$ and $\mathrm{NaFeO}_{2}$ may be slightly present in the ash samples.

Figure 5 depicts typical Raman spectra of the three ash samples in the range $1200-950 \mathrm{~cm}^{-1}$. As for UA1-1, a Raman band was only observed at $1078 \mathrm{~cm}^{-1}$ in nearly half of measurement points, and no bands were detected at the other points. Conversely, multi-Raman peaks appeared in almost all of the UA1-2 spectra. It is interesting to note that all the spectra of UA2 exhibited the strong Raman bands at around $1078 \mathrm{~cm}^{-1}$.

In general, Raman bands appearing in this frequency region are due to a stretching vibration of the superoxide anion, $\mathrm{O}_{2}^{-}$, with respect to substances comprising mainly oxides such as UA samples. The vibrational bands of this anion in a number of compounds have been reported, and they were detected over a relatively wide frequency-range [12-16]. Accordingly, Raman bands shown in Fig. 5 are likely to be assigned to the vibrational mode of superoxide anions, excluding those appearing at around $1078 \mathrm{~cm}^{-1}$.
Table 3 Molar ratios of $\mathrm{Fe} / \mathrm{Ca}, \mathrm{Fe} /(\mathrm{Na}+\mathrm{Mg}+\mathrm{Ca}), \mathrm{Na} / \mathrm{Ca}$, and $\mathrm{Mg} /$ $\mathrm{Ca}$

\begin{tabular}{lllll}
\hline $\begin{array}{l}\text { Umoregi- } \\
\text { wood ash } \\
\text { samples }\end{array}$ & \multicolumn{4}{l}{ Molar ratio } \\
\cline { 2 - 5 } & $\mathrm{Fe} / \mathrm{Ca}$ & $\mathrm{Fe} /(\mathrm{Na}+\mathrm{Mg}+\mathrm{Ca})$ & $\mathrm{Na} / \mathrm{Ca}$ & $\mathrm{Mg} / \mathrm{Ca}$ \\
\hline $\mathrm{UA1} 1$ & $0.993(2)$ & $0.666(4)$ & $0.207(4)$ & $0.284(2)$ \\
$\mathrm{UA1}-2$ & $0.830(2)$ & $0.571(4)$ & $0.153(4)$ & $0.300(3)$ \\
$\mathrm{UA2}$ & $0.334(1)$ & $0.166(1)$ & $0.872(7)$ & $0.146(1)$ \\
\hline
\end{tabular}

Error ranges were estimated from the standard deviations shown in Table 1

It is well known that the carbonates of metals belonging to Groups 1 and 2 have a Raman-active vibrational band at $\sim 1080 \mathrm{~cm}^{-1}$; moreover, $\mathrm{Na}_{2} \mathrm{O}$ and $\mathrm{CaO}$ readily react with $\mathrm{CO}_{2}$ in air and change to their carbonates. As shown in Tables 1 and 3, the total molar percentage of $\mathrm{Na}$, $\mathrm{Mg}$, and $\mathrm{Ca}$ is much larger than that of Fe in UA samples, especially in UA2. Thus, it is likely that $\mathrm{Na}_{2} \mathrm{O}, \mathrm{MgO}$, and $\mathrm{CaO}$ other than their ferrites were produced more or less by the combustion of umoregi wood. In particular, UA2 probably include considerable amounts of $\mathrm{Na}_{2} \mathrm{O}$ and $\mathrm{CaO}$ when the burning of UW2 was completed; therefore, the Raman bands observed at $1085-1073 \mathrm{~cm}^{-1}$ would be due to stretching vibrations of $\mathrm{CO}_{3}{ }^{2-}$ ion.

Figure 6 depicts Raman spectra of $\mathrm{MA}$ and $\mathrm{CaCO}_{3}$ in the range $1200-150 \mathrm{~cm}^{-1}$. The line-shapes of all observed Raman spectra of MA were nearly independent of the measurement points in a sample. The Raman spectral shape of MA is the same as that of neat $\mathrm{CaCO}_{3}$, indicating

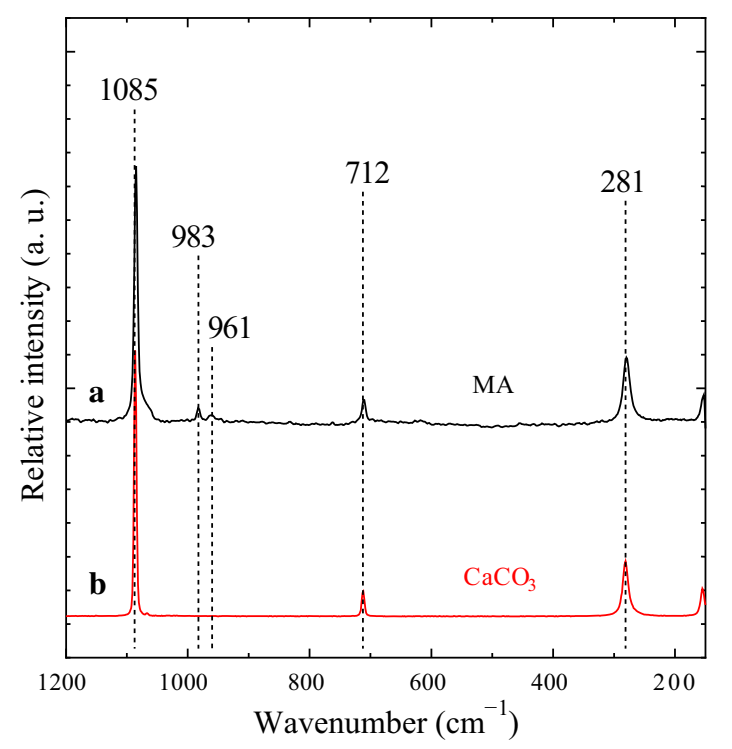

Fig. 6 Raman spectra in the range $1200-150 \mathrm{~cm}^{-1}$ of ash samples for a MA (black solid line) and $\mathbf{b} \mathrm{CaCO}_{3}$ (red solid line) MA was made from modern Japanese cedar wood 


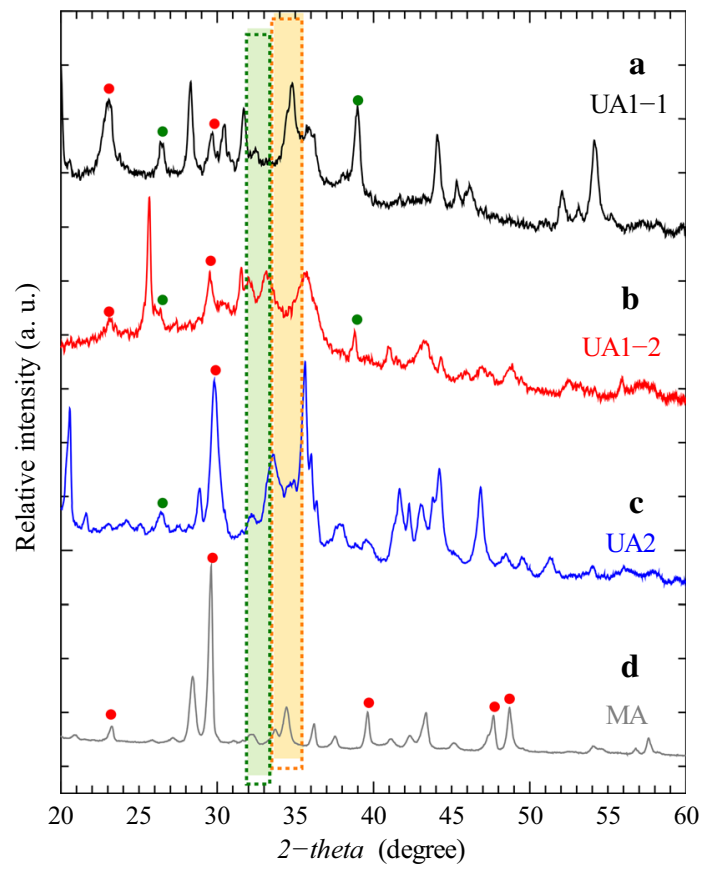

Fig. 7 XRD patterns of ash samples for a UA1-1 (black solid line), b UA1-2 (red solid line), c UA2 (blue solid line), and MA (gray solid line) Red full circles and blue full circles show the peaks due to calcite-type and aragonite-type $\mathrm{CaCO} 3$, respectively. Green and orange zones are 2-theta ranges in which characteristic XRD peaks due to $\mathrm{Ca}_{2} \mathrm{Fe}_{2} \mathrm{O}_{5}$ and $\mathrm{CaFe}_{2} \mathrm{O}_{4}$, respectively, appear

that the bands at around $1078 \mathrm{~cm}^{-1}$ are assigned to stretching vibrational modes of the $\mathrm{CO}_{3}{ }^{2-}$ ion.

Another possible reaction of the metal oxides in air is hydrolysis; however, no $\mathrm{OH}$ stretching vibrational bands were detected on the three ash samples by Raman spectroscopy. Hence, it is concluded that the ash samples do not contain any hydroxides and oxyhydroxides.

\section{XRD patterns of ash samples}

Figure 7 illustrates XRD patterns in the 2-theta range $20-60^{\circ}$ of ash powder samples. The four XRD patterns may be entirely different from one another. All three XRD patterns of umoregi-wood ash samples show multi-peaks in the 2theta regions in which the characteristic XRD peaks due to $\mathrm{Ca}_{2} \mathrm{Fe}_{2} \mathrm{O}_{5}$ (green zone) and $\mathrm{CaFe}_{2} \mathrm{O}_{4}$ (orange zone) should be observed; however, the peaks are not well-resolved. Moreover, the XRD pattern of MA also exhibits peaks in green and orange zones in the figure despite little or no calcium ferrites. Accordingly, it is likely difficult to identify the calcium ferrites in the umoregi-wood ash samples on the basis of the XRD data.

In contrast with the calcium ferrites, several peaks attributable to $\mathrm{CaCO}_{3}$ are detected in the XRD patterns of all ash

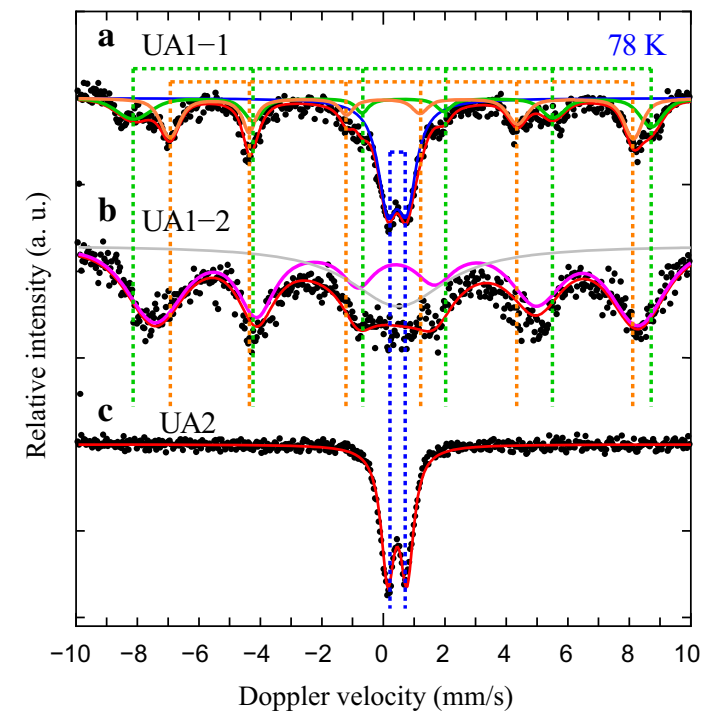

Fig. 8 Mössbauer spectra $78 \mathrm{~K}$ of ash samples for a UA1-1, b UA1-2, and c UA2 Red solid curves correspond to the sum of spectral components. Orange and green solid curves correspond to $O_{h}$ and $T_{d}$ sites in $\mathrm{Ca}_{2} \mathrm{Fe}_{2} \mathrm{O}_{5}$, respectively. UAX was made from UWX (X=1-1, $1-2$, and 2). Vertical dotted lines correspond to peak positions of two sextets and a doublet in UA1-1 spectrum

samples, confirming the assignment of Raman band around $1078 \mathrm{~cm}^{-1}$.

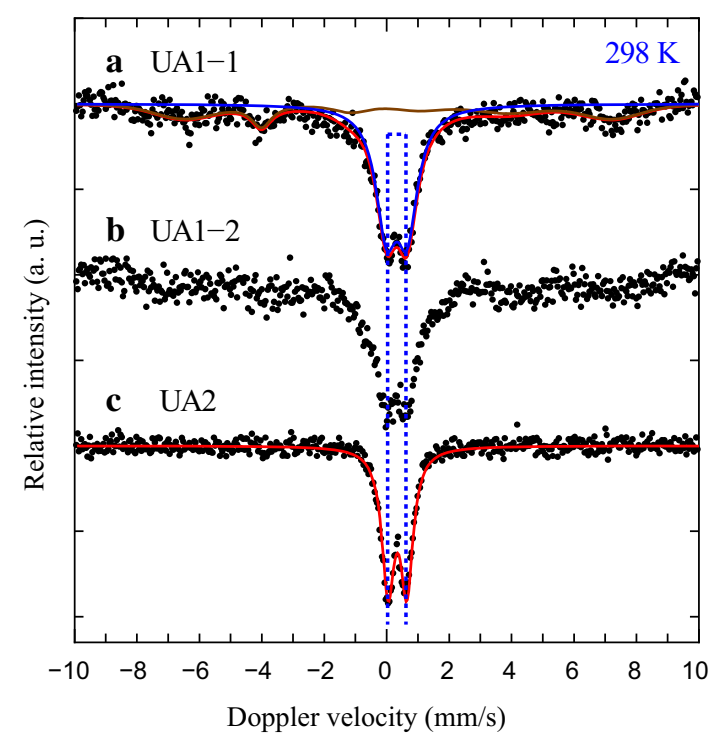

Fig. 9 Mössbauer spectra $298 \mathrm{~K}$ of ash samples for a UA1-1, b UA12 , and c UA2 Red solid curve corresponds to the sum of spectral components. UAX was made from UWX $(X=1-1,1-2$, and 2). Vertical dotted lines correspond to peak positions of a doublet in UA1-1 spectrum 


\section{Mössbauer spectra of ash samples}

Figures 8 and 9 display Mössbauer spectra of umoregi-wood ash samples at $78 \mathrm{~K}$ and $298 \mathrm{~K}$, respectively. With respect to Mössbauer measurements at $78 \mathrm{~K}$, the complicated spectral profiles due to magnetic hyperfine splitting are observed in the spectra of UA1-1 and UA1-2, while only a quadrupole doublet is recorded in that of UA2. On the other hand, the primary absorption is a doublet line in the three spectra at $298 \mathrm{~K}$, although the spectrum of UA1-1 and UA1-2 seems to possess weak absorptions on both sides of the doublet. The Mössbauer spectra of UA2 (78 K and $298 \mathrm{~K}$ ) were successfully analyzed using the ordinary curve-fitting procedure on the assumption that they consist of a Lorentzian-shaped doublet absorption. However, we could not obtain reliable Mössbauer parameters for the UA1-1 and UA1-2 spectra using the ordinary method, owing to their broad and complicated line-shapes.

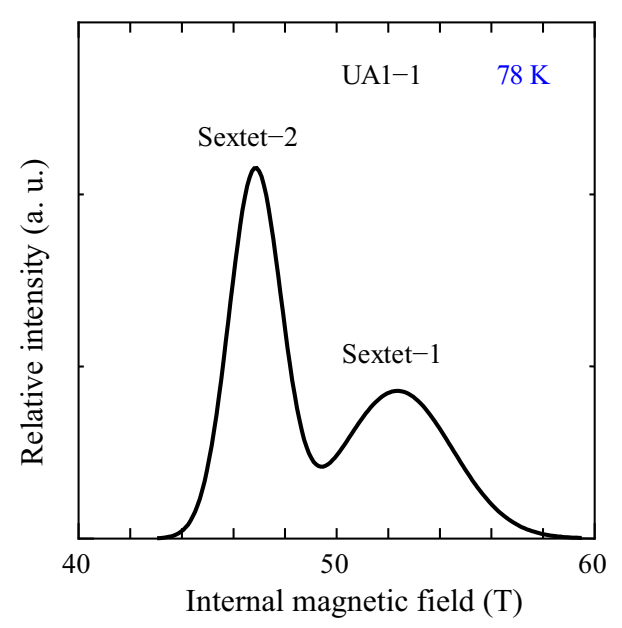

Fig. 10 Distributions of internal magnetic field $(H)$ in Mössbauer spectra at $78 \mathrm{~K}$ of UA1-1 for internal magnetic field $(H)$ of Mössbauer absorptions corresponding to two sextets
The most likely explanation for the broadening and complication in Mössbauer absorption lines might be the multichemical iron-bearing species, leading to the wide-range distribution of their $I S, Q S$, and $H$ values. Thus, the three spectra were numerically re-analyzed using by the curve-fitting procedure with a distribution of Mössbauer parameters, the principle of which was developed by Hesse and Rübartsch [17]. A typical example of the obtained distributions is shown in Fig. 10, where the hyperfine-field distribution for the UA1-1 spectrum at $78 \mathrm{~K}$. Finally, the procedure provided satisfactory results with respect to the spectrum of UA1-1 at $78 \mathrm{~K}$. These Mössbauer parameters of the ash samples are listed in Table 4, and Mössbauer parameters of sodium [18, 19], magnesium [20, 21], and calcium [5, 18, 22-24] ferrites reported previously are summarized in Table 5 .

As shown in Fig. 8, the Mössbauer spectrum at $78 \mathrm{~K}$ of UA1-1 was resolved into a doublet and two sextets. By comparing the Mössbauer data reported previously [23], the Mössbauer parameters calculated on the two sextets are probably attributed to the two $\mathrm{Fe}^{3+}$ sites in $\mathrm{Ca}_{2} \mathrm{Fe}_{2} \mathrm{O}_{5}$. Moreover, the doublet line in the spectrum would also be assigned to $\mathrm{Ca}_{2} \mathrm{Fe}_{2} \mathrm{O}_{5}$ in terms of the $I S$ and $Q S$ values. A likely explanation for the disappearance of magnetic hyperfine splitting is due to a superparamagnetic effect, namely a part of $\mathrm{Ca}_{2} \mathrm{Fe}_{2} \mathrm{O}_{5}$ powder is less than $\sim \mathrm{nm}$. Because this effect increases more remarkably as temperature increases [25], the explanation is supported by the fact that the ratio of the whole sextet absorption intensity to the doublet absorption intensity at $298 \mathrm{~K}$ is extremely weak, as compared with that at $78 \mathrm{~K}$.

Hirabayashi and co-workers asserted that the product yields of $\mathrm{Ca}_{2} \mathrm{Fe}_{2} \mathrm{O}_{5}$ and $\mathrm{CaFe}_{2} \mathrm{O}_{4}$ synthesized from $\mathrm{Fe}_{2} \mathrm{O}_{3}$ and $\mathrm{CaO}$ at $1000{ }^{\circ} \mathrm{C}$ depended upon the $\mathrm{Fe} / \mathrm{Ca}$ molar ratio in the reactant [5]. They reported that Fe-containing compounds as the reaction products were only the two calcium ferrites when the $\mathrm{Fe} / \mathrm{Ca}$ value is more than 0.67 , and the yield of $\mathrm{Ca}_{2} \mathrm{Fe}_{2} \mathrm{O}_{5}$ decreased with increasing $\mathrm{Fe} / \mathrm{Ca}$ ratio in the range from 0.67 to 2 . The percentage of $\mathrm{Ca}_{2} \mathrm{Fe}_{2} \mathrm{O}_{5}$

Table 4 Mössbauer parameters of UA1-1, UA1-2, and UA2

\begin{tabular}{|c|c|c|c|c|c|c|c|c|}
\hline Sample & Temp.(K) & Type of absorption & $I S(\mathrm{~mm} / \mathrm{s})$ & $Q S(\mathrm{~mm} / \mathrm{s})$ & $H(\mathrm{~T})$ & $L W(\mathrm{~mm} / \mathrm{s})$ & Area $(\%)$ & Primary Fe species \\
\hline \multirow[t]{5}{*}{ UA1-1 } & \multirow[t]{3}{*}{78} & Doublet & $0.45(1)$ & $0.62(1)$ & - & $0.74(5)$ & $42(1)$ & - \\
\hline & & Sextet-1 D & $0.47(2)$ & $-0.34(4)$ & $52.4[2]$ & $0.51(5)$ & $27(2)$ & $\mathrm{Ca}_{2} \mathrm{Fe}_{2} \mathrm{O}_{5}\left(O_{h}\right.$ site $)$ \\
\hline & & Sextet-2 D & $0.30(1)$ & $0.60(3)$ & $46.8[1]$ & $0.51(5)$ & $31(2)$ & $\mathrm{Ca}_{2} \mathrm{Fe}_{2} \mathrm{O}_{5}\left(T_{d}\right.$ site $)$ \\
\hline & \multirow[t]{2}{*}{298} & Doublet & $0.32(2)$ & $0.66(2)$ & - & $0.82(5)$ & $64(1)$ & - \\
\hline & & Sextet D & $0.2(5)$ & $0.4(1)$ & $43[5]$ & $0.8(2)$ & $36(5)$ & - \\
\hline \multirow[t]{2}{*}{ UA1-2 } & \multirow[t]{2}{*}{78} & Singlet & $0.49(5)$ & - & - & - & $30(4)$ & - \\
\hline & & Sextet D & $0.43(1)$ & $0.00(3)$ & $49[3]$ & - & $70(5)$ & - \\
\hline \multirow[t]{2}{*}{ UA2 } & 78 & Doublet & $0.454(3)$ & $0.627(4)$ & - & $0.524(7)$ & 100 & - \\
\hline & 298 & Doublet & $0.345(3)$ & $0.601(6)$ & - & 0.49 (1) & 100 & - \\
\hline
\end{tabular}

$I S$ isomer shift; $Q S$ quadrupole splitting; $H$ internal magnetic field; T tesla; $L W$ line width; $O_{h}$ octahedral; $T_{d}$ tetrahedral 
Table 5 Mössbauer parameters of sodium, magnesium, and calcium ferrites reported previously

\begin{tabular}{|c|c|c|c|c|c|c|c|}
\hline Ferrites & Chemical sate of iron & Type of splitting & Temp. (K) & $I S(\mathrm{~mm} / \mathrm{s})$ & $Q S(\mathrm{~mm} / \mathrm{s})$ & $H(\mathrm{~T})$ & Ref. \\
\hline \multirow[t]{3}{*}{$\alpha-\mathrm{NaFeO}_{2}$} & $\mathrm{Fe}^{3+}$ & Doublet & 77 & 0.47 & 0.45 & - & [18] \\
\hline & $\mathrm{Fe}^{3+}$ & Doublet & 295 & 0.36 & 0.48 & - & [18] \\
\hline & $\mathrm{Fe}^{3+}$ & Doublet & 283 & 0.22 & 0.23 & - & [19] \\
\hline \multirow[t]{2}{*}{$\beta-\mathrm{NaFeO}_{2}$} & $\mathrm{Fe}^{3+}$ & Sextet & 295 & 0.17 & 0.05 & 49.0 & [18] \\
\hline & $\mathrm{Fe}^{3+}$ & Sextet & 283 & 0.194 & -0.057 & 49.35 & [19] \\
\hline \multirow[t]{8}{*}{$\mathrm{MgFe}_{2} \mathrm{O}_{4}$} & $\mathrm{Fe}^{3+}\left(O_{h}\right)$ & Sextet & 300 & 0.38 & 0.01 & 44.1 & [20] \\
\hline & $\mathrm{Fe}^{3+}\left(T_{d}\right)$ & Sextet & 300 & 0.22 & 0.05 & 41.3 & [20] \\
\hline & $\mathrm{Fe}^{3+}\left(O_{h}\right)$ & Sextet-1 & 300 & 0.32 & -0.01 & 49.5 & [21] \\
\hline & $\mathrm{Fe}^{3+}\left(O_{h}\right)$ & Sextet-2 & 300 & 0.03 & 0.36 & 49.9 & [21] \\
\hline & $\mathrm{Fe}^{3+}\left(T_{d}\right)$ & Sextet & 300 & 0.26 & -0.01 & 44.7 & [21] \\
\hline & $\mathrm{Fe}^{3+}\left(O_{h}\right)$ & Sextet-1 & 78 & 0.48 & 0.025 & 54.3 & [21] \\
\hline & $\mathrm{Fe}^{3+}\left(O_{h}\right)$ & Sextet-2 & 78 & 0.44 & -0.064 & 53.9 & [21] \\
\hline & $\mathrm{Fe}^{3+}\left(T_{d}\right)$ & Sextet & 78 & 0.36 & 0.004 & 51.7 & [21] \\
\hline \multirow[t]{7}{*}{$\mathrm{CaFe}_{2} \mathrm{O}_{4}$} & $\mathrm{Fe}^{3+}$ & Sextet & 78 & 0.48 & -0.031 & 46.2 & [5] \\
\hline & $\mathrm{Fe}^{3+}$ & Doublet & 293 & 0.37 & 0.52 & - & [5] \\
\hline & $\mathrm{Fe}^{3+}$ & Sextet & 77 & 0.45 & 0.00 & 46.0 & [18] \\
\hline & $\mathrm{Fe}^{3+}$ & Doublet-1 & 295 & 0.37 & 0.33 & - & [18] \\
\hline & $\mathrm{Fe}^{3+}$ & Doublet-2 & 295 & 0.37 & 0.74 & - & [18] \\
\hline & $\mathrm{Fe}^{3+}$ & Doublet-1 & 295 & 0.37 & 0.30 & - & [22] \\
\hline & $\mathrm{Fe}^{3+}$ & Doublet-2 & 295 & 0.37 & 0.75 & - & [22] \\
\hline \multirow[t]{8}{*}{$\mathrm{Ca}_{2} \mathrm{Fe}_{2} \mathrm{O}_{5}$} & $\mathrm{Fe}^{3+}\left(O_{h}\right)$ & Sextet & 77 & 0.46 & -0.52 & 54.0 & [23] \\
\hline & $\mathrm{Fe}^{3+}\left(T_{d}\right)$ & Sextet & 77 & 0.27 & 0.71 & 47.5 & [23] \\
\hline & $\mathrm{Fe}^{3+}\left(O_{h}\right)$ & Sextet & 300 & 0.37 & -0.52 & 50.4 & [23] \\
\hline & $\mathrm{Fe}^{3+}\left(T_{d}\right)$ & Sextet & 300 & 0.18 & 0.72 & 42.9 & [23] \\
\hline & $\mathrm{Fe}^{3+}\left(O_{h}\right)$ & Sextet & 293 & 0.35 & -0.52 & 50.7 & [5] \\
\hline & $\mathrm{Fe}^{3+}\left(T_{d}\right)$ & Sextet & 293 & 0.18 & 0.72 & 43.2 & {$[5]$} \\
\hline & $\mathrm{Fe}^{3+}\left(O_{h}\right)$ & Sextet & RT & 0.36 & -0.54 & 51.5 & [24] \\
\hline & $\mathrm{Fe}^{3+}\left(T_{d}\right)$ & Sextet & $\mathrm{RT}$ & 0.18 & 0.72 & 43.9 & [24] \\
\hline
\end{tabular}

$I S$ isomer shift; $Q S$ quadrupole splitting; $H$ internal magnetic field; $T$ tesla; $R T$ room temperature $O_{h}$ octahedral; $T_{d}$ tetrahedral was $\sim 78 \%$ at a ratio of $\mathrm{Fe} / \mathrm{Ca}$ of 1.0 and reached a maximum value ( 96\%) at 0.67 . However, the yield of $\mathrm{Ca}_{2} \mathrm{Fe}_{2} \mathrm{O}_{5}$ decreased with the decrease in the $\mathrm{Fe} / \mathrm{Ca}$ molar ratio when the $\mathrm{Fe} / \mathrm{Ca}$ value was less than 0.67 , and fell to $~ 87 \%$ at 0.33 .

On the other hand, the $\mathrm{Fe} / \mathrm{Ca}$ molar ratio in UA1-1 is 0.993 as shown in Table 3; therefore, the percentage of $\mathrm{Ca}_{2} \mathrm{Fe}_{2} \mathrm{O}_{5}$ was estimated to be $\sim 80 \%$ according to Hirabayashi's study [5]. However, Fe in UA1-1 was shared with $\mathrm{Ca}, \mathrm{Na}$, and $\mathrm{Mg}$, and hence, the actual $\mathrm{Fe} / \mathrm{Ca}$ ratio should be considerably smaller than 0.993 , because the $\mathrm{Fe} /(\mathrm{Ca}+\mathrm{Na}+\mathrm{Mg})$ molar ratio is 0.666 . Furthermore, the $\mathrm{Na} / \mathrm{Ca}$ and $\mathrm{Mg} / \mathrm{Ca}$ molar ratios are calculated as 0.207 and 0.284 , respectively (Table 3 ). Thus, it can be assumed that $\mathrm{Ca}_{2} \mathrm{Fe}_{2} \mathrm{O}_{5}$ occupies most of the Fe-containing species in UA1-1. In addition, the Mössbauer parameter values at $78 \mathrm{~K}$ of two sextets for UA1-1 show slight differences form those for $\mathrm{Ca}_{2} \mathrm{Fe}_{2} \mathrm{O}_{5}$ reported previously [23], suggesting that small amounts of the other ferrites, $\mathrm{CaFe}_{2} \mathrm{O}_{4}, \beta-\mathrm{NaFeO}_{2}$, and $\mathrm{MgFe}_{2} \mathrm{O}_{4}$ might be present in UA1-1.
As described above, it was claimed from our Mössbauer results that the primary iron-species might be $\mathrm{Ca}_{2} \mathrm{Fe}_{2} \mathrm{O}_{5}$ in UA1-1. First, we tried to analyze the Mössbauer line-shape for UA1-2 at $78 \mathrm{~K}$, assuming that there could be three components (one doublet and two sextets) all with parameter distributions as well as for UA1-1. However, on such an assumption, we could not obtain any satisfactory fitting result. As results of trial and error, it is found at last that the line shape is consist of one sextet with parameter distribution and one broaden singlet, as shown in Fig. 8 and Table 4 .

This curve-fitting result is provisionally explained in the followings. All the peak-tops with the sextet line (purple solid curve) in UA1-2 spectrum occupy intermediate positions between those with the two sextet lines (green and orange solid curves) in UA1-1 spectrum, suggesting that $\mathrm{Ca}_{2} \mathrm{Fe}_{2} \mathrm{O}_{5}$ is also present as a primary $\mathrm{Fe}$-containing species in UA1-2. In addition, small amounts of the other ferrites are also expected in UA1-2. 
As for UA2, the Fe/Ca molar ratio is estimated to be 0.372 , suggesting that the primary Fe-containing species might be also $\mathrm{Ca}_{2} \mathrm{Fe}_{2} \mathrm{O}_{5}$ same as in UA1-1 and UA1-2. Apparently, both the spectra at $78 \mathrm{~K}$ and $298 \mathrm{~K}$ consist of only a doublet, and their Mössbauer parameters, $I S$ and $Q S$, are explained as unresolved absorptions due to two $\mathrm{Fe}^{3+}$ sites $\left(O_{h}\right.$ and $\left.T_{d}\right)$ in $\mathrm{Ca}_{2} \mathrm{Fe}_{2} \mathrm{O}_{5}$. No observation of magnetic hyperfine splitting even at $78 \mathrm{~K}$ indicate that the powder including whole $\mathrm{Ca}_{2} \mathrm{Fe}_{2} \mathrm{O}_{5}$ in UA2 is much finer than that in UA1-1 or UA1-2 in terms of the superparamagnetic phenomenon. The Raman measurements suggest the presence of $\beta-\mathrm{NaFeO}_{2}$, the Mössbauer spectrum of which shows magnetic hyperfine splitting even at room temperature $[18,19]$. Here, however, no magnetic hyperfine splitting is observed in UA2. This probably indicates that $\beta-\mathrm{NaFeO}_{2}$ is also included in powder finer than $\sim 5 \mathrm{~nm}$ as well as $\mathrm{Ca}_{2} \mathrm{Fe}_{2} \mathrm{O}_{5}$. Mössbauer absorption due to $\beta-\mathrm{NaFeO}_{2}$ should appear to be a singlet because of its very small $Q S$; however, the absorption is expected not to be revolved from the primary doublet lines because of its weak intensity.

Mössbauer characterization suggests that the primary $\mathrm{Fe}$ containing species is a calcium ferrite, $\mathrm{Ca}_{2} \mathrm{Fe}_{2} \mathrm{O}_{5}$, in every ash sample.

\section{Factors governing the color tone of umoregi-wood ash}

Here, we comprehensively discuss the chemical components affecting on the color tone of the ash samples.

Based on the results obtained from Mössbauer and Raman characterization, it is confirmed that $\mathrm{Ca}_{2} \mathrm{Fe}_{2} \mathrm{O}_{5}$ is the primary Fe-containing species in the three umoregi-wood ash samples. The mineral name of $\mathrm{Ca}_{2} \mathrm{Fe}_{2} \mathrm{O}_{5}$ is brownmillerite, the several studies on which have reported that synthesized $\mathrm{Ca}_{2} \mathrm{Fe}_{2} \mathrm{O}_{5}$ powder looked dark brown [26], brown [23], or dark red [7]. Consequently, we conclude that the dark-brown color of the UA1-1 ash sample is due mainly to $\mathrm{Ca}_{2} \mathrm{Fe}_{2} \mathrm{O}_{5}$. It was reported that powder products of $\mathrm{CaFe}_{2} \mathrm{O}_{4}$ [27-29], $\mathrm{MgFe}_{2} \mathrm{O}_{4}[9,30,31]$, and $\mathrm{NaFeO}_{2}$ [32] look reddish, brownish or blackish colors; therefore, small amounts of other ferrites, even if existing, presumably have little effect on the color of UA1-1.

As shown in Table 3, the $\mathrm{Fe} / \mathrm{Ca}$ and $\mathrm{Fe} /(\mathrm{Na}+\mathrm{Mg}+\mathrm{Ca})$ molar ratios for UA1-2 are slightly smaller than those for UA1-1. This finding suggests that the ratio of $\mathrm{Ca}_{2} \mathrm{Fe}_{2} \mathrm{O}_{5}$ to whole Fe-containing species for UA1-2 could be equal to or slightly larger than that for UA1-1. If so, UA1-2 should look dark brown like UA1-1; however, the color tone of UA1-2 is orange and much brighter than that of UA1-1. This indicates that the factors affecting the color tone of UA1-2 other than $\mathrm{Fe}$-containing species need to be searched in terms of the whole components of the ash.
There are two important differences between the constituent elements in UA1-1 and UA1-2. Firstly, the molar percentage of Fe in UA1-2 is considerably smaller than that in UA1-1; therefore, the mass ratio of $\mathrm{Ca}_{2} \mathrm{Fe}_{2} \mathrm{O}_{5}$ to whole ash for UA1-2 should also be smaller than that for UA1-1.

Secondly, S and P in UA1-2, especially S, are extremely abundant compared with UA1-1. Nevertheless, there is no positive evidence that iron sulfides were produced by the combustion of UW1-2. Most species of iron sulfide in powder turn black or dark gray; hence, any iron sulfides probably do not contribute to the orange color even if iron sulfides were generated in UA1-2. In contrast, all the sulfides of $\mathrm{Na}, \mathrm{Mg}$, and $\mathrm{Ca}$ are generally white or colorless. Furthermore, phosphorus sulfides, $\mathrm{P}_{4} \mathrm{~S}_{3}, \mathrm{P}_{2} \mathrm{~S}_{5}$, and $\mathrm{P}_{4} \mathrm{~S}_{7}$ show light-yellow colors. Thus, phosphorus sulfides may contribute to orange color of UA1-2 if some of the sulfides are contained in the ash sample, although we have no experimental evidence that they are produced by burning UW 1-2.

As described above, it is assumed that the UA2 ash sample has $\mathrm{Ca}_{2} \mathrm{Fe}_{2} \mathrm{O}_{5}$ as the primary Fe-containing species like UA1-1 and UA1-2. However, UA2 shows a grayish-yellow color, which is entirely different from the other ash samples. Since the molar ratios of $\mathrm{Fe}$ to $\mathrm{Na}$ and $\mathrm{Ca}$ for UA2 are extremely small compared with those for UA1-1 and UA1-2 as shown in Table 3, oxides and/or carbonates of $\mathrm{Na}$ and $\mathrm{Ca}$, which are white, should be present much more abundantly in UA2 than in UA1-1 and UA1-2. Accordingly, $\mathrm{Ca}_{2} \mathrm{Fe}_{2} \mathrm{O}_{5}$ in UA2 is substantially diluted by oxides and/or carbonates of $\mathrm{Na}$ and $\mathrm{Ca}$, so that UA2 appear to be grayish-yellow.

Calcium ferrite, $\mathrm{Ca}_{2} \mathrm{Fe}_{2} \mathrm{O}_{5}$, plays a key role in determining the color tone of the umoregi-wood ash examined in this study. When an actual Fe/Ca molar ratio greatly exceeds 1.0, another calcium ferrite, $\mathrm{CaFe}_{2} \mathrm{O}_{4}$, also presumably has a considerable effect on the color of umoregi-wood ash. However, $\mathrm{CaFe}_{2} \mathrm{O}_{4}$ appears as a brownish or blackish color as well as $\mathrm{Ca}_{2} \mathrm{Fe}_{2} \mathrm{O}_{5}$, as described above. Thus, it is likely that the color of umoregi-wood ash is influenced by the molar percentage of $\mathrm{Fe}$ rather than the $\mathrm{Fe} / \mathrm{Ca}$ molar ratio. The oxides and carbonates of $\mathrm{Ca}, \mathrm{Mg}$, and $\mathrm{Na}$, would act to dilute the brown color due to ferrites, and the dilution effect increases in ash with a decrease in the molar percentage of Fe. Additionally, the particle size of ash also probably affects the color.

\section{Conclusion}

The present work provided positive evidence that $\mathrm{Ca}_{2} \mathrm{Fe}_{2} \mathrm{O}_{5}$ can be produced by burning the Japanese cedar umoregiwood excavated from Nikaho City in Japan, and confirmed that the brownish color tone of umoregi-wood ash examined in this study is due to the presence of $\mathrm{Ca}_{2} \mathrm{Fe}_{2} \mathrm{O}_{5}$, the mineral 
name of which is "brownmillerite". It was concluded that the color tone of umoregi-wood ash mainly depends on the molar percentage of $\mathrm{Fe}$ in ash. Moreover, this characterization of Fe suggested that ash of umoregi wood usually contains several different kinds of ferrites.

The factors affecting the color of umoregi-wood ash are very complicated, and further studies on a wider range of umoregi-wood samples are required to classify the ash samples by their colors and to investigate the coloring mechanisms in detail.

Acknowledgements Part of this study was supported by 2019 grant for research in Geoparks from Akita Prefecture Geopark Liaison Council. The authors are deeply grateful to the Liaison Council for the grant.

Open Access This article is licensed under a Creative Commons Attribution 4.0 International License, which permits use, sharing, adaptation, distribution and reproduction in any medium or format, as long as you give appropriate credit to the original author(s) and the source, provide a link to the Creative Commons licence, and indicate if changes were made. The images or other third party material in this article are included in the article's Creative Commons licence, unless indicated otherwise in a credit line to the material. If material is not included in the article's Creative Commons licence and your intended use is not permitted by statutory regulation or exceeds the permitted use, you will need to obtain permission directly from the copyright holder. To view a copy of this licence, visit http://creativecommons.org/licenses/by/4.0/.

\section{References}

1. Yamauchi S, Kurimoto Y, Sakai Y (2017) Mössbauer spectroscopic characterization of iron in ashes made from the ancient woods excavated in the foothills of Mt. Chokai. J Nucl Radiochem Sci 17:1-7

2. Yamauchi S, Kurimoto Y, Sakai Y (2017) Mössbauer characterization of iron in ancient buried trees excavated from the foothills of Mt. Chokai. J Nucl Radiochem Sci 17:23-29

3. Kurimoto Y, Yamauchi S, Takayama T, Sakai Y (2020) Coloring mechanisms of ancient buried wood: Japanese cedar trees excavated from the foothills of Mt. Chokai. J Wood Sci 66:24-29

4. Sakurai H, Kato W, Takahashi Y, Suzuki K, Takahashi Y, Gunji S, Tokanai F (2006) 14C dating of 2500-yr-old Choukai jindai cedar tree rings from Japan using highly accurate LSC measurement. Radiocarbon 48:401-408

5. Hirabayashi D, Sakai Y, Yoshikawa T, Mochizuki K, Kojima Y, Suzuki K, Ohshita K, Watanabe Y (2006) Mössbauer characterization of calcium-ferrite oxides prepared by calcining $\mathrm{Fe}_{2} \mathrm{O}_{3}$ and $\mathrm{CaO}$. Hyperfine Interact 167:809-813

6. Miller DD, Siriwardane R (2018) $\mathrm{CaFe}_{2} \mathrm{O}_{4}$ oxygen carrier characterization during the partial oxidation of coal in the chemical looping gasification application. Appl Energy 224:708-716

7. Piovano A, Ceretti M, Johnson MR, Agostini G, Paulus W, Lamberti $\mathrm{C}$ (2015) Anisotropy in the Raman scattering of a $\mathrm{CaFeO}_{2.5}$ single crystal and its link with oxygen ordering in Brownmillerite frameworks. J Phys: Condens Matter 27:225403-225414

8. Phan T-L, Tran N, Kim DH, Tho PT, Huy BT, Dang TN, Yang D-S, Lee B (2018) Electronic structure and magnetic properties of Al-doped $\mathrm{Ca}_{2} \mathrm{Fe}_{2} \mathrm{O}_{5}$ brownmillerite compounds. J Am Ceram Soc 101:2181-2189
9. Wang Z, Lazor P, Saxena SK, O’Neill HStC (2002) High pressure Raman spectroscopy of ferrite $\mathrm{MgFe}_{2} \mathrm{O}_{4}$. Mater Res Bull 37:1589-1602

10. Feng Y, Li S, Zheng Y, Yi Z, He Y, Zu Y (2017) Preparation and characterization of $\mathrm{MgFe}_{2} \mathrm{O}_{4}$ nanocrystallites via PVA sol-gel route. J Alloys Compd 699:521-525

11. Ohtori N, Furukawa T, Ueno F (2005) In situ Raman spectroscopic observation of corrosion reaction of $\mathrm{Fe}$ with $\mathrm{Na}_{2} \mathrm{O}_{2}$ up to 833 K. Electrochem 73:675-679

12. Zecchina A, Spoto G, Coluccia S (1982) Surface dioxygen adducts on $\mathrm{Mg}-\mathrm{CoO}$ solid solutions: analogy with cobalt-based homogeneous oxygen carriers. J Mol Catal 14:351-355

13. Giamello E, Sojka Z, Che M, Zecchina A (1986) Spectroscopic study of superoxide formed by low-temperature adsorption of oxygen onto cobalt oxide ( $\mathrm{CoO})$-magnesium oxide solid solutions: an example of synthetic heterogeneous oxygen carriers. J Phys Chem 90:6084-6091

14. Fujita S, Nakano H, Suzuki K, Mori T, Masuda H (2003) Oxidative destruction of hydrocarbons on a new zeolite-like crystal of $\mathrm{Ca}_{12} \mathrm{Al}_{10} \mathrm{Si}_{4} \mathrm{O}_{35}$ including $\mathrm{O}_{2}^{-}$and $\mathrm{O}_{2}{ }^{2-}$ radicals. Chem Mater 15:255-263

15. Sato K, Iritani J, Miyamoto R, Fujita S, Suzuki K, Ohkawa M, Mori T (2005) Reactivity of superoxide ions $\left(\mathrm{O}_{2}^{-}\right)$occluded in micropores of calcium aluminosilicate varied via substitution with transition metal ions. Stud Surf Sci Catal 158B:2001-2008

16. Hayyan M, Hashim MA, AlNashef IM (2016) Superoxide ion: generation and chemical implications. Chem Rev 116:3029-3085

17. Hesse J, Rübartsch A (1974) Model independent evaluation of overlapped Mössbauer spectra. J Phys E: Sci Instrum 7:526-532

18. Birchall T, Greenwood NN, Reid AF (1969) Mössbauer, electron resonance, optical, and magnetic studies of iron(III) in oxide host lattices. J Chem Soc A 1:2382-2398

19. Korecki J, Obuszko Z, Riesenkampf W, Styczyńska M (1982) Néel point of $\beta-\mathrm{NaFeO}_{2}$. Acta Phys Polonica A62:395-400

20. Randhawa BS, Gandotra K (2007) Application of Mössbauer spectroscopy in thermal decomposition studies of some metal ferricarboxylates. Ind J Pure Appl Phys 45:795-799

21. Widatallah HM, Al-Mamari FAS, Al-Saqri NAM, Gismelseed AM, Al-Omari IA, Al-Shahum TMH, Alhaj AF, Abo El Ata AM, Elzain ME (2013) Mössbauer and magnetic studies of $\mathrm{Mg}_{1+2 \mathrm{x}} \mathrm{Sb}_{\mathrm{x}} \mathrm{Fe}_{2-3 \mathrm{x}} \mathrm{O}_{4}$ spinel ferrites. Mat Chem Phys 140:97-103

22. Tsipis EV, Pivak YV, Waerenborgh JC, Kolotygin VA, Viskup AP, Kharton VV (2007) Oxygen ionic conductivity, Mössbauer spectra and thermal expansion of $\mathrm{CaFe}_{2} \mathrm{O}_{4-\delta}$. Solid State Ion 178:1428-1436

23. Randhawa BS, Sweety K (2000) Calcium ferrite formation from the thermolysis of calcium tris(maleato)ferrate(III). Bull Mater Sci 23:305-307

24. Shaula AL, Pivak YV, Waerenborgh JC, Gaczyñski P, Yaremchenko AA, Kharton VV (2006) Ionic conductivity of brownmillerite-type calcium ferrite under oxidizing conditions. Solid State Ion 177:2923-2930

25. Greneche J-M (2013) In: Yoshida Y, Langouche G (eds) Mössbauer spectroscopy. Springer, Berlin

26. Nishida T, Kubuki S, Shibata M, Maeda Y, Tamaki T (1997) Crystallization mechanism of aluminoferrate glass accompanying a precipitation of nanocrystals of dicalcium ferrite $\left(\mathrm{Ca}_{2} \mathrm{Fe}_{2} \mathrm{O}_{5}\right)$ and mayenite $\left(12 \mathrm{CaO} \cdot 7 \mathrm{Al}_{2} \mathrm{O}_{3}\right)$. J Mater Chem 7:1801-1806

27. Goodarzi M, Joukar S, Ghanbari D, Hedayati K (2017) $\mathrm{CaFe}_{2} \mathrm{O}_{4}-\mathrm{ZnO}$ magnetic nanostructures: photo-degradation of toxic azo-dyes under UV irradiation. J Mater Sci: Mater Electron 28:12823-12838

28. Lal G, Punia K, Dolia SN, Alvi PA, Dalela S, Kumar S (2019) Rietveld refinement, Raman, optical, dielectric, Mössbauer and magnetic characterization of superparamagnetic fcc- $\mathrm{CaFe}_{2} \mathrm{O}_{4}$ nanoparticles. Ceram Int 45:5837-5847 
29. Ali AS, Ishikawa S, Nomura K, Kuzmann E, Homonnay Z, Scrimshire A, Bingham PA, Krehula S, Ristic M, Musić S, Kubuki S (2019) Mössbauer and photocatalytic studies of $\mathrm{CaFe}_{2} \mathrm{O}_{4}$ nanoparticle-containing aluminosilicate prepared from domestic waste simulated slag. J Radioanal Nucl Chem 322:1469-1476

30. Jeseentharani V, George M, Jeyaraj B, Dayalan A, Nagaraja KS (2013) Synthesis of metal ferrite $\left(\mathrm{MFe}_{2} \mathrm{O}_{4}, \mathrm{M}=\mathrm{Co}, \mathrm{Cu}, \mathrm{Mg}, \mathrm{Ni}\right.$, $\mathrm{Zn}$ ) nanoparticles as humidity sensor materials. J Exp Nanosci $8: 358-370$

31. Kirchberg K, Becker A, Bloesser A, Weller T, Timm J, Suchomski C, Marschall R (2017) Stabilization of monodisperse, phase-pure
$\mathrm{MgFe}_{2} \mathrm{O}_{4}$ nanoparticles in aqueous and nanoaqueous media and their photocatalytic behavior. J Phys Chem C 121:27126-27138

32. Bakaimi I, Papadopulou EL, Kenanakis G, Spanakis E, Lappas A (2018) Thin film growth of delafossite-related derivative $\beta-\mathrm{NaFeO}_{2}$ on a $\mathrm{ZnO}$ layer by pulsed laser deposition. Thin Solid Firms 645:424-430

Publisher's Note Springer Nature remains neutral with regard to jurisdictional claims in published maps and institutional affiliations. 